\title{
Selected Aspects of Carbon Stock Assessment in Aboveground Biomass
}

\author{
Vilém Pechanec $1, * \mathbb{*}$, Lenka Štěrbová ${ }^{2} \mathbb{D}$, Jan Purkyt ${ }^{2,3}$, Marcela Prokopová ${ }^{2}$, Renata Včeláková ${ }^{2}$, \\ Ondřej Cudlín ${ }^{2}$, Pavel Vyvlečka ${ }^{1}$ (I) Emil Cienciala ${ }^{2,4}$ (i) and Pavel Cudlín ${ }^{2}$ (D)
}

1 Department of Geoinformatics, Faculty of Science, Palacký University Olomouc, 17. listopadu 50, 77146 Olomouc, Czech Republic; pavel.vyvlecka@upol.cz

2 Global Change Research Institute of the Czech Academy of Sciences Lipová 1789/9, 37005 České Budějovice, Czech Republic; sterbova.1@czechglobe.cz (L.Š.); purkyt.j@czechglobe.cz (J.P.); prokopova.m@czechglobe.cz (M.P.); vcelakova.r@czechglobe.cz (R.V.); cudlin.o@czechglobe.cz (O.C.); emil.cienciala@ifer.cz (E.C.); cudlin.p@czechglobe.cz (P.C.)

3 Department of Landscape Management, Faculty of Agriculture, University of South Bohemia in České Budějovice, Studentská 787/13, 37005 České Budějovice, Czech Republic

4 IFER Institute of Forest Ecosystem Research, Čs.armády 655, 25401 Jílové u Prahy, Czech Republic

* Correspondence: vilem.pechanec@upol.cz; Tel.: +420-586-345-79

Citation: Pechanec, V.; Štěrbová, L.; Purkyt, J.; Prokopová, M.; Včeláková, R.; Cudlín, O.; Vyvlečka, P.; Cienciala,

E.; Cudlín, P. Selected Aspects of

Carbon Stock Assessment in

Aboveground Biomass. Land 2022, 11, 66. https://doi.org/10.3390/ land11010066

Academic Editor: Agata Novara

Received: 18 November 2021

Accepted: 30 December 2021

Published: 2 January 2022

Publisher's Note: MDPI stays neutral with regard to jurisdictional claims in published maps and institutional affiliations.

Copyright: (C) 2022 by the authors. Licensee MDPI, Basel, Switzerland. This article is an open access article distributed under the terms and conditions of the Creative Commons Attribution (CC BY) license (https:// creativecommons.org/licenses/by/ $4.0 /)$.

\begin{abstract}
Given the significance of national carbon inventories, the importance of large-scale estimates of carbon stocks is increasing. Accurate biomass estimates are essential for tracking changes in the carbon stock through repeated assessment of carbon stock, widely used for both vegetation and soil, to estimate carbon sequestration. Objectives: The aim of our study was to determine the variability of several aspects of the carbon stock value when the input matrix was (1) expressed either as a vector or as a raster; (2) expressed as in local $(1: 10,000)$ or regional $(1: 100,000)$ scale data; and (3) rasterized with different pixel sizes of 1, 10, 100, and $1000 \mathrm{~m}$. Method: The look-up table method, where expert carbon content values are attached to the mapped landscape matrix. Results: Different formats of input matrix did not show fundamental differences with exceptions of the biggest raster of size $1000 \mathrm{~m}$ for the local level. At the regional level, no differences were notable. Conclusions: The results contribute to the specification of best practices for the evaluation of carbon storage as a mitigation measure, as well as the implementation of national carbon inventories.
\end{abstract}

Keywords: carbon stock; degree of data detail; different space resolution; rasterization

\section{Introduction}

Ecosystems regulate the global climate by storing greenhouse gases. The process of carbon sequestration decreases the concentration of $\mathrm{CO}_{2}$ during photosynthesis; although the majority of carbon is returned to the atmosphere through autotrophic and heterotrophic respiration [1,2], part of it becomes effectively locked in plant tissues during the growth of biomass [3,4] and in soil complexes [1]. Carbon sequestration mitigates climate change only if there is a net additional transfer of carbon from atmospheric $\mathrm{CO}_{2}$ to the terrestrial biosphere (vegetation or soil), which can be achieved by (i) increasing net photosynthesis, for example, by planting new areas of trees or grass, or (ii) slowing the rate of decomposition of soil organic carbon through changes in land management, for example, reducing intensity of tillage or altering management of water [5].

Carbon stock is the quantity of carbon at a given time and therefore does not provide information about trends, which is necessary for sequestration assessment [5]. However, accurate biomass estimates are essential for tracking changes in the carbon stock through repeated assessment of carbon stock [6], widely used for both vegetation [7] and soil [5,8], to estimate carbon sequestration.

Aboveground biomass constitutes a crucial portion of the carbon pool, according to the Intergovernmental Panel on Climate Change (IPCC) [9]. Carbon-stock estimation is 
a basis for modeling carbon productivity and sequestration [10,11]. These are mainly for regional-scale carbon models $[12,13]$ or for models assessing trajectories in biomass trends such as LandTredr [14,15], or large-scale sequestration models such as the InVest model [4], which is widely used for regional or national studies [16-18]. Carbon-stock assessment is also necessary for the creation of stored carbon and carbon-sequestration maps, which are useful tools for providing decision-making support [19] to prevent carbon-rich ecosystems from becoming carbon sources [20] as a consequence of inappropriate management or land-cover changes, e.g., deforestation [9].

\subsection{The Importance of Carbon Sequestration as an Ecosystem Service}

Carbon sequestration and carbon storage belong to the regulating service categories called carbon sequestration and storage or carbon sequestration by terrestrial ecosystems, according to The Economics of Ecosystems and Biodiversity [21] and The Common International Classification of Ecosystem Services (CICES), respectively. They are perhaps the most recognized among all ecosystem services [22-24].

The concept of ecosystem services was designed to help solve complex socio-ecological problems [25] and to support decision making and governance of the entire range of assets in nature upon which humans depend [26-28]. Ecosystem functions (EFs) are closely related to ecosystem processes and have been described by various definitions, for example, as interactions within and among ecosystems [29] and, in a broader context, as energy and matter transfer $[30,31]$. However, these definitions do not separate EFs from ecosystem or ecological processes [32].

Ecosystem functions become ecosystem services when humans consider them useful in terms of material (goods) and nonmaterial (services) benefits. The term "ecosystem service" is defined as a benefit delivered by an ecosystem to humans that influences human quality of life, according to Millennium Ecosystem Assessment (MEA). The distinction between ecosystem functions and services is not consistent. Ecosystem functions are perceived as a precondition for final ecosystem services production [33-35]; they can be described as the capacity of an ecosystem to deliver ecosystem goods and services that fulfill human needs [36]. Often, ecosystem functions are considered a service when they can be ascribed an economical value [29], but this approach fails to establish the distinction between ecosystem functions and ecosystem services. Petter et al. [37] noted that functions can have both intrinsic and potential anthropocentric value, whereas services are defined only in terms of their benefits to people. The definition provided by Meyer et al. [38] states that ecosystem services are those functions and products of an ecosystem that directly or indirectly benefit humans.

Based on the definition of global climate regulation, which consists of the reduction in greenhouse-gas concentrations, distinct indicators such as carbon stored in vegetation and soils [39-41] and carbon sequestration [42,43] have been recommended. Tools combining biophysical quantification with economical valuation into maps, facilitating spatially explicit assessment and modeling, are available for general use [44-47].

Forests, meadows and grasslands, bogs, peatlands, and other terrestrial ecosystems together store almost three times as much carbon as there is in the atmosphere [48]. Forests were identified to be the key category of land use and land-use change in the forestry sector of the Kyoto protocol, deserving the most attention [22]. The maintenance of these carbon reservoirs is among the highest priorities because their potential to reduce deforestation and degradation far exceeds the importance of afforestation activities in climate-change mitigation [49]. Nabuurs et al. [50] characterized different options of forest management to maintain or maximize forest carbon pools and carbon sequestration. Nonforest ecosystems also stock significant amounts of carbon, mainly in soils [51]. To prevent excessive carbon release, inappropriate management such as an intensification [52,53] or conversion of grasslands into arable land [54] should be avoided. 


\subsection{Methods of Collecting Data on Carbon Sequestration}

Methods for determining carbon stocks can be divided into two basic groups: contact and contactless methods. Methods based on contact measurements provide the most accurate results but are highly costly and time consuming [55-57]. Contactless methods, based on the remote sensing (RS) acquisition of image data (multispectral or radar), show considerable potential for determining the carbon content of vegetation biomass. In inaccessible areas, they are the only method available to determine the carbon content of the vegetation cover [58-60].

The basic methods of the contact approach are the forestry inventory, production tables, and eddy covariance methods. Forestry inventory, or national forest inventory (NFI), is a common approach to assessing biomass and carbon stocks based on parameters implemented during ground exploration [61-63]. Ponce-Hernandez [64] described the principle of tree allometry in detail in connection with the measurement of carbon in biomass. Allometry, namely the biomass expansion factor (BEF) and biomass equations, is often one of main challenges in NFI use [62,65]. This is partly due to the expansion factors and equations being based on local studies [62], which may also be affected by the biomass growth in spruce forests that are recently significantly accelerating [66]. Cienciala et al. [6] used a database of forest management plans to estimate carbon-stock changes using speciesspecific, age-dependent, biomass conversion-expansion factors. The authors compared the results with estimates based on NFI, finding that NFI provided slight underestimation, and stressed the importance of input data accuracy and the recalculation factors used. MainKnorn et al. [10] compared carbon stocks assessed using forest inventories with estimates derived from satellite data analysis.

The production-tables method (look-up table method) is based on the link between individual categories and the prepared values of carbon stock or production. This method was derived from previous contact measurements and literature knowledge and is implemented in several models, e.g., InVEST and NLLUF-KP10 $[16,67,68]$. Another method is the eddy covariance method, which is based on the direct measurement of $\mathrm{CO}_{2}$ flux, which is very accurate but measures direct $\mathrm{CO}_{2}$ flux only over small areas $[63,69]$.

\subsection{Differences between Methods and the Level of Uncertainty}

Methods used for carbon-stock assessment also vary according to the applied scale: harvest methods for the plot/local scale [70], the combination of measured data and allometric equations for the local to semi-regional scale, and remote-sensing methods for the regional, national or global scale [71]. Within large-scale biomass mapping, differences in expert data and allometric equations used, either empirical [61,72] or modeled [73,74], may lead to large uncertainties [75]. The models of productivity further use biomass expansion factors, which are another source of uncertainty in carbon accounting on the national level [76]. Several studies comparing forest above-ground biomass using two or more assessment methods demonstrated a certain variability in the results $[10,73,77]$, and variability was also detected within assessments of soil carbon [78]. The calibration and validation of remote sensing data based on accurate ground (plot) reference measurements of biomass are therefore recommended $[79,80]$.

Land-cover change is one driver of carbon sequestration [81]. Considering the change rates and time required for ground-based monitoring, it is appropriate to use remote sensing methods, which are still being improved [82] and provide important advantages (speed, repeatability, coverage width, non-destructive approach) [83]. Inventory methods naturally differ in the scale and size of the evaluated area, amongst others $[84,85]$. One method of transmitting information from different temporal and spatial levels is scaling. Scaling is the process that describes objects and phenomena based on the changing scale of geographical data and comprises two important components: grain and extent [86]. Zhao et al. [81] quantified and evaluated the impact of land-cover-change databases on various spatial resolutions $(250 \mathrm{~m}, 500 \mathrm{~m}, 1 \mathrm{~km}, 2 \mathrm{~km}$, and $4 \mathrm{~km}$ pixel edges) on the magnitude and spatial patterns of regional carbon sequestration. The results supported the use of a threshold of 
$1 \mathrm{~km}$ in the land-cover-change databases and for the estimated regional terrestrial-carbon sequestration. Muñoz-Rojas et al. [87] assessed the temporal and spatial variability in the carbon stored in vegetation by comparing accurate spatial datasets adapted to the Corine land-cover nomenclature. This methodology allows the analysis of carbon-sequestration trends associated with land-use changes.

\subsection{Data Processing into the Resulting Map}

The obtained input data are heterogeneous both in terms of the format of the transmitted data and in spatial distribution. Therefore, geographic information system (GIS) resources are often used today for their processing in the form of carbon-stock maps $[18,88,89]$. The most suitable method is chosen based on the scale used and the area of interest. Landscape matrices are one of the dominant methods used for determining reserves at the landscape (habitat) level, based on expert valuation. However, the choice of matrix form and detail is an important aspect that affects the final carbon stock [81].

In terms of data format (for expressing the landscape matrix), we have the choice of vector or raster. The vector format is characterized by the possibility of much more accurately capturing details of the border and attribute tables with useful information. The ability to capture the exact course of the boundaries is a trade-off with a larger volume of data and greater complexity in computational operations. The raster border does not completely cover the defined shape, and it is necessary to choose whether to use a raster that will contain only fully contained pixels, or to use the part that touches the border. In both cases, however, the area of interest and/or the analyzed matrix changes, and the boundaries are simplified. Another disadvantage of the raster is the elimination of small segments; conversely, its advantage is good compression properties. An important parameter that affects the resulting representation of the area of interest is the size of the cell. In general, the smaller the cell, the more accurately are the course of the boundaries of the studied area captured, and the smaller the cell size, the greater are the memory space requirements [90]. The different representations of the results depending on the cell size are shown in Figure 1.
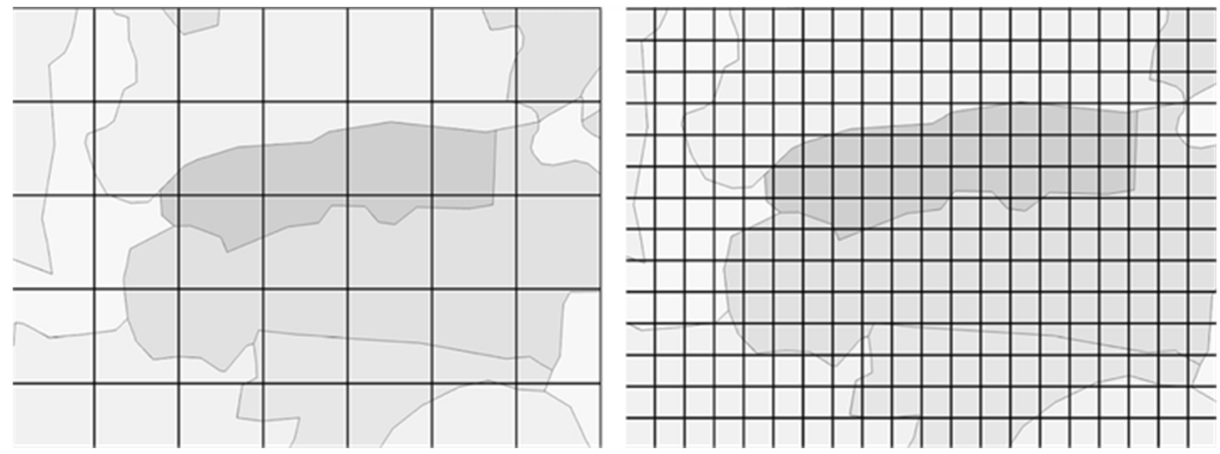

Figure 1. Influence of raster cell size on the resulting representation of the region of interest.

Some questions remain: how big of a difference is the carbon stock when using a vector or raster matrix, and how does this ratio change depend on the size of the studied area?

The aims of our study were (i) to demonstrate the variability in carbon stocks between two measurement scales (differently detailed land-use matrices) and three different extents of the area of interest (representing the local, regional, and national scales) and (ii) to determine the variability in carbon stocks on the same scales when using two different methods for assessment. The evaluated results contribute to the determination of the optimal degree of data detail for the analysis of ecosystem services (especially carbon sequestration) at the landscape level. 


\section{Materials and Methods}

The whole data processing was carried out in ArcGIS Pro 2.6.2 software (Esri Inc. Redlands, CA, USA) in the national coordinate system (epsg: 5514). All monitored factors were analyzed in three study areas of various sizes (Table 1). At the highest level, the area of interest was the entire country (the Czech Republic). A description of the natural conditions in the country was given by Pechanec et al. [91]. The Dřevnice catchment area is located in the southeastern part of the Czech Republic (Figure 2), and the Všemina catchment area is located in the northwestern part of the Dřevnice River basin. For a more detailed description, see Pechanec et al. [92].

Table 1. Characteristics of the study areas.

\begin{tabular}{|c|c|c|c|c|}
\hline \multicolumn{2}{|c|}{ Scale } & Local & Regional & National \\
\hline \multicolumn{2}{|c|}{ Name } & Všemina & Dřevnice & Czech Republic \\
\hline \multicolumn{2}{|c|}{ Area (hectare) } & 2153.28 & $43,519.10$ & $7,886,680.71$ \\
\hline \multicolumn{2}{|c|}{ Method of delimitation } & $\begin{array}{l}\text { Natural borders: } \\
\text { small-size d } \\
\text { catchment }\end{array}$ & $\begin{array}{c}\text { Natural borders: } \\
\text { medium-sized catchment }\end{array}$ & $\begin{array}{l}\text { Administrative } \\
\text { boundaries: state }\end{array}$ \\
\hline \multicolumn{2}{|c|}{ Elevation $\min (\mathrm{m}$ a.s.l.) } & 275 & 200 & 120 \\
\hline \multicolumn{2}{|c|}{ Elevation max (m a.s.l.) } & 575 & 725 & 1603 \\
\hline \multicolumn{2}{|c|}{ Elevation mean (m a.s.1.) } & 407 & 352 & 447 \\
\hline \multicolumn{2}{|c|}{ Elevation median (m a.s.l.) } & 400 & 336 & 435 \\
\hline \multicolumn{2}{|c|}{ Geological subsoil } & $\begin{array}{l}\text { flysch layers with } \\
\text { calcareous claystones } \\
\text { and glauconitic } \\
\text { sandstones }\end{array}$ & $\begin{array}{c}\text { flysch layers with } \\
\text { calcareous claystones and } \\
\text { glauconitic sandstones }\end{array}$ & - \\
\hline \multicolumn{2}{|c|}{ Predominant soil types } & Mesobasic Cambisol & $\begin{array}{l}\text { dominated lightly gley } \\
\text { Eutric Cambisol and } \\
\text { Stagno-gleyic Cambisol }\end{array}$ & - \\
\hline \multicolumn{2}{|c|}{ Annual average daily temperature $\left({ }^{\circ} \mathrm{C}\right)$} & 8.6 & 8.5 & 7.9 \\
\hline \multicolumn{2}{|c|}{ Annual average total precipitation (mm) } & 772 & 776 & 681 \\
\hline \multirow{5}{*}{$\begin{array}{c}\text { Land cover category } \\
\text { (According CLC } \\
\text { 2018) (ha) }\end{array}$} & Artificial surfaces & 223.79 & 5014.17 & $525,428.92$ \\
\hline & Agricultural area & 772.17 & $19,761.68$ & $4,480,658.16$ \\
\hline & $\begin{array}{c}\text { Forest and } \\
\text { seminatural areas }\end{array}$ & 1157.32 & $18,629.28$ & $2,811,715.24$ \\
\hline & Wetlands & 0.0 & 0.0 & $10,666.11$ \\
\hline & Water bodies & 0.0 & 113.98 & $58,212.27$ \\
\hline
\end{tabular}

\section{Look-Up Table Method}

In the present study, the fundamental methodological approach for carbon-stock estimation was based on the currently widely used look-up table (LUT) method (Figure 3), where expertly determined values are attached to the mapped landscape matrix to quantify the carbon stocks. 


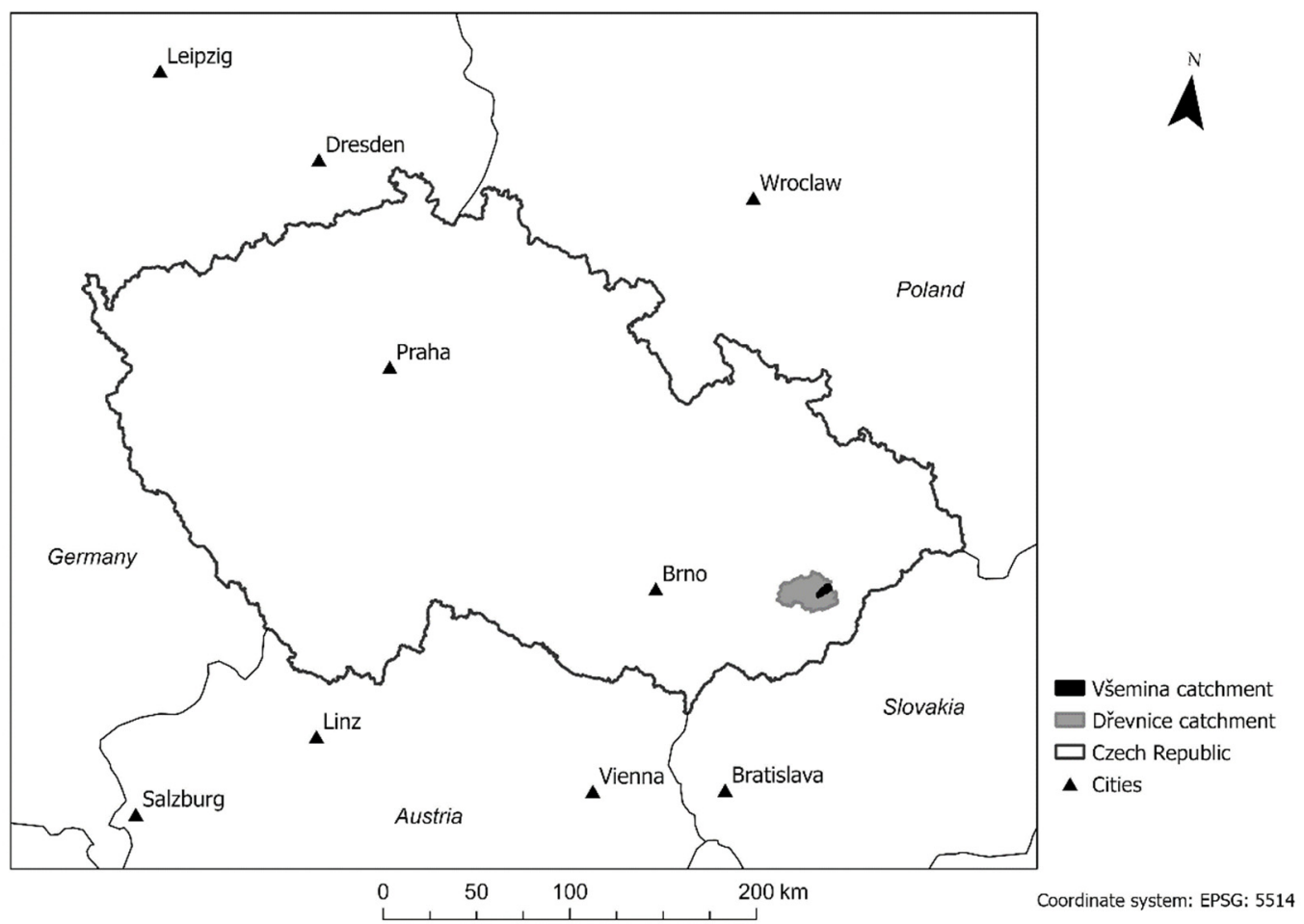

Figure 2. Location of studied areas. All data were used in the national coordinate system EPSG: 5514. In order to preserve the principle of downscaling and the possibility of comparing and controlling values, the studied areas are overlapped.

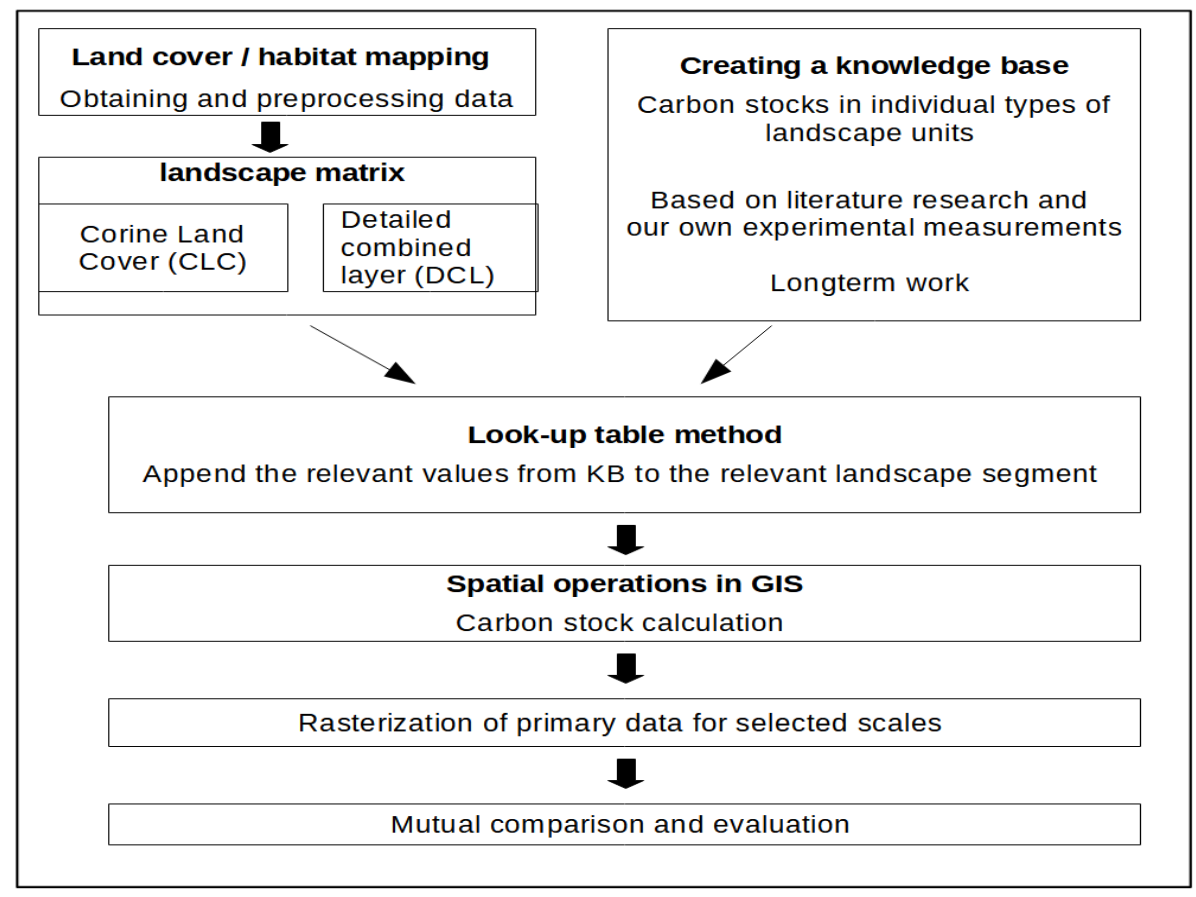

Figure 3. Overview of the used methodology (detailed description in the text).

To describe the landscape matrix, two layers delineating the current land cover were used (Table 2). 
Table 2. Characteristics of GIS layers used to determine the actual land cover.

\begin{tabular}{|c|c|c|}
\hline Name & Corine Land Cover (CLC) & Detailed Combined Layer (DCL) \\
\hline Updated to (year) & 2018 & 2018 \\
\hline Scale & $1: 100,000$ & $1: 10,000$ \\
\hline Max. number of categories & 20 natural and 8 unnatural & 154 natural and 38 unnatural habitats \\
\hline Data availability & $\begin{array}{c}\text { Free, without limitations, } \\
\text { https: / / land.copernicus.eu/pan- } \\
\text { european/ corine-land-cover, accessed } \\
\text { on } 1 \text { November } 2021\end{array}$ & Non-public layer \\
\hline Format & Vector, ESRI geodatabase & Vector, ESRI geodatabase \\
\hline Data owner & ESA@ & Czechglobe $\odot$ \\
\hline Notes & - & $\begin{array}{l}\text { The layer is composed of (1) habitat mapping layer } \\
\text { (NCA CR @ , 2015) for natural and near-nature } \\
\text { habitats and (2) modified Consolidated layer of } \\
\text { ecosystems of the Czech Republic (C CzechGlobe (C) } \\
\text { NCA CR, 2013) for unnatural habitats. }\end{array}$ \\
\hline
\end{tabular}

As the Corine land-cover classes are relatively broadly defined, mapped in coarse grain, and most classes usually consist of a variety of different habitats [93], we needed to know characteristics of particular CLC classes more in detail. For this, we used the habitat mapping layer (NCA CR 2015) and CzechTerra land-cover data from the landscape inventory system [94] and conducted spatial analysis of these two datasets for each class of CLC layer in ArcGIS. An additional classification of randomly selected $10 \times 10 \mathrm{~m}$ squares over aerial photographs was used in the case of missing data, using the same classification as in Šímová et al. [94]. Afterwards, all the land-use classes of the CzechTerra landscape inventory system, as well as habitats of the habitat-mapping layer, were expressed as 127 natural habitats, according to Chytrý et al. [95] and 38 unnatural habitats, according to Seják et al. [96]. We obtained the detailed composition of each individual CLC class, expressed as a proportion of particular habitats [96]. We had to solve a similar problem for the rather broadly defined unnatural habitat classes in the detailed combined layer, defined previously in the consolidated layer of ecosystems of the Czech Republic [97]. Proportions of particular habitats according to Seják et al. [98] were obtained using a set of randomly distributed points spread throughout the whole Czech Republic for any single class and classified over aerial photographs.

The carbon stocks for the most frequently occurring habitats (from natural to unnatural habitats), according to Seják et al. [98], were assessed using literature research and our own experimental measurements [99]. From the results of the first and second cycles of the Czech Terra landscape inventory project $[100,101]$ (http:/ / www.czechterra.cz, accessed on 1 November 2021), we derived the annual increase in tree biomass, along with annual harvested wood volume in the period 2010-2019 [102], which was used to estimate the actual total aboveground biomass of forests. The harvested wood volume for August/September 2020 was hypothesized to be the same amount as in 2019. The harvested area and per-hectare yield of grain green, and silage maize provided by Czech Statistical Office (https:/ / www.czso.cz/csu/czso/zem_cr, accessed on 1 November 2021) were used to calculate the aboveground biomass on arable land. Practically all other crops are harvested in July and September, so they were not considered. The net carbon storage was calculated by multiplying the biomass dry weight values by a coefficient of 0.46 or 0.5 for tree biomass [22]. Only living aboveground biomass in tons of carbon per hectare was used to compare the LUT and RS methods [16]. The biomass of forest understory vegetation and dead wood mass were not included in the aboveground biomass.

For each segment of landscape matrix, the dominant habitat type/land cover category was determined, and the corresponding carbon-stock value from the expert table was 
attached to it. This value was multiplied by the segment area to produce the carbon stock in the given segment. In the end, the carbon stocks of individual segments were summed for the whole study area. Following this method, the carbon stock was estimated in the (base) vector form of both matrices.

Next, the matrix data were rasterized into defined resolutions (pixel sizes of 1, 10, 100 , and $1000 \mathrm{~m}$ ). The rasterization was conducted separately for each study area from the original vector matrix with the already-attached carbon values from the expert table. The maximum combined area algorithm was applied; if there is more than one feature in a cell with the same value, the areas of these features are combined. The combined feature with the largest area within the cell determines the value to assign to the cell [103]. The coefficients were multiplied by the pixel area, and the individual values were summed for the whole study area.

The carbon values were multiplied by pixel area and summed for the whole study area. Finally, we calculated the absolute relative change of a carbon sequestration metric $\delta_{i}$ :

$$
\delta_{i}=\frac{C_{i}-C_{\text {vector }}}{C_{\text {vector }}}
$$

where $C_{i}$ is the maximum of the annual carbon sequestration rates at spatial resolution $i$ $(i=1,10,100$, or $1000 \mathrm{~m}), C_{\text {vector }}$ is stock found in primary (vector) data.

To facilitate comparison across different statistics, we normalized $\delta_{i}$ :

$$
\operatorname{delta}_{i}=\frac{\delta_{i}}{\max \delta_{i}} \times 100
$$

where $\max \delta_{i}$ is the maximum absolute value for each spatial resolution $i(i=1,10,100$, or $1000 \mathrm{~m})$.

\section{Results}

3.1. Comparison of Carbon Stock, Assessed on the Basis of Local-or Regional-Scale Data in Vector Form

Comparing the carbon stock in the same area, with the Detailed Combined Layer used on the local scale, the assessed carbon stock was higher than with the Corine Land Cover vector data used on the regional scale, namely by $6.1 \%$ in the Všemina catchment, by $6.6 \%$ in the Dřevnice catchment, and by $5.7 \%$ in the Czech Republic.

\subsection{Comparison of Carbon Stock Assessed on the Basis of Vector and Raster Data with a Pixel Size of $1 \mathrm{~m}$}

Comparing the results of carbon-stock assessment based on data from the vector and raster forms with a $1 \mathrm{~m}$ pixel size with the Detailed Combined Layer, almost no difference was found in all study areas (Table 3). At the local and regional scales, there were only negligible distinctions at the level of $0.01 \%$.

To better explain the determined differences in carbon stocks computed for individual studied areas, the contribution of forests to total aboveground carbon stock was assessed (Table 4). The average carbon stock of the aboveground biomass per hectare was higher in both catchment areas compared to the Czech Republic (V̌̌emina catchment $61.5 \%$, Dřevnice catchment 50\%, and Czech Republic 41.7\%) and corresponded to the percentage of forests from the whole territory (Všemina catchment 54.1\%, Dřevnice catchment $44.1 \%$, and Czech Republic $35.7 \%$ ). As the contribution of forests to total aboveground carbon stock was very high in all three areas and ranged between $96.1 \%$ and $97.4 \%$, the percentage of forests in the studied area can be identified as the main factor influencing the carbon stock in the area. 
Table 3. Aboveground carbon stock (tons of Carbon; $\mathrm{tC}$ ) estimated on the basis of vector and raster data in all three studied areas.

\begin{tabular}{ccccccc}
\hline & \multicolumn{2}{c}{ Všemina Catchment } & \multicolumn{2}{c}{ Dřevnice Catchment } & \multicolumn{2}{c}{ The Czech Republic } \\
\hline DCL (local level) & $\mathrm{tC}$ & delta $_{i}{ }^{*}$ & $\mathrm{t} \mathrm{C}$ & delta $_{i}$ & $\mathrm{t} \mathrm{C}$ & delta $_{i}$ \\
vector & 132,311 & 100.00 & $2,174,717$ & 100.00 & $328,959,273$ & 100.00 \\
raster (px_1 m) & 132,308 & 100.00 & $2,174,696$ & 100.00 & $328,944,499$ & 99.99 \\
raster (px_10 m) & 131,881 & 99.67 & $2,168,092$ & 99.70 & $330,010,591$ & 100.32 \\
raster (px_100 m) & 129,576 & 97.93 & $2,127,636$ & 97.84 & $327,003,892$ & 99.41 \\
raster (px_1000 m) & 89,597 & 67.72 & $1,965,140$ & 90.36 & $327,261,780$ & 99.48 \\
\hline CLC (regional level) & & & & & & \\
vector & 124,238 & 100.00 & $2,030,350$ & 100.00 & $310,156,013$ & 100.00 \\
raster (px_1 m) & 124,238 & 100.00 & $2,030,348$ & 99.99 & $310,142,056$ & 99.99 \\
raster (px_10 m) & 124,248 & 100.01 & $2,030,402$ & 100.00 & $310,154,681$ & 100.00 \\
raster (px_100 m) & 124,399 & 100.13 & $2,027,924$ & 99.88 & $310,172,172$ & 100.01 \\
raster (px_1000 m) & 119,580 & 96.25 & $2,074,358$ & 102.17 & $302,717,755$ & 97.60 \\
\hline
\end{tabular}

* Values were calculated according to Equations (1) and (2).

Table 4. Contribution of forests' total aboveground carbon stock (according to Detailed Combined Layer).

\begin{tabular}{cccc}
\hline & Všemina Catchment & Dřevnice Catchment & The Czech Republic \\
\hline $\begin{array}{c}\text { Average carbon stock of aboveground } \\
\text { biomass }\left(\mathrm{tC} \times \mathrm{ha}^{-1}\right)\end{array}$ & 61.5 & 50.0 & 41.7 \\
\hline Forest coverage $(\%)$ & 54.1 & 44.1 & 35.7 \\
\hline Forests \% of total aboveground carbon stock & 97.4 & 97.1 & 96.1 \\
\hline
\end{tabular}

The use of different land-cover matrices and experimenting with rasterization caused large differences in the number of segments of the individual tested layers (Table 5). The comparison of the number of segments composing a landscape matrix revealed that the number of landscape-matrix segments in vector form at the regional level (38 in Všemina, 391 in Dřevnice, and 45,982 in the Czech Republic) was closest to the number of segments in raster form with a $1000 \mathrm{~m}$ pixel size (21 in Všemina catchment, 429 in Dřevnice catchment, and 78,713 in the Czech Republic).

Table 5. Number of segments in individual landscape matrices on the basis of vector and raster data for all studied areas.

\begin{tabular}{cccc}
\hline Number of Segments & Všemina Catchment & Dřevnice Catchment & The Czech Republic \\
\hline DCL (local level) & & & $3,397,878$ \\
vector & 1496 & 24,531 & $78,868,865,357$ \\
raster (px_1 m) & $21,532,725$ & $435,190,835$ & $788,681,413$ \\
raster (px_10 m) & 215,324 & $4,351,803$ & $7,885,708$ \\
raster (px_100 m) & 2142 & 43,454 & 78,637 \\
raster (px_1000 m) & 20 & 424 & 45,982 \\
CLC (regional level) & 38 & 391 & $78,866,788,417$ \\
vector & $21,532,741$ & $435,190,903$ & $788,667,223$ \\
raster (px_1 m) & 215,331 & $4,351,897$ & $7,886,305$ \\
raster (px_10 m) & 2149 & 43,493 & 78,713 \\
raster (px_100 m) & 21 & 429 & \\
raster (px_1000 m) & & \\
\hline
\end{tabular}

\subsection{Effect of Data of Various Pixel Sizes on the Carbon-Stock Assessment at the Local Level}

The comparison of carbon stocks calculated using the raster dataset of the Detailed Combined Layer with different pixel sizes showed very small differences in carbon-stock 
estimations for all study areas using pixel sizes of 1, 10, and $100 \mathrm{~m}$, with $2.16 \%$ representing the highest difference. The largest carbon stock was detected using a pixel size of $1 \mathrm{~m}$ with the exception of the whole Czech Republic, where the largest value was calculated using 10 m pixels; however, the difference was only $0.32 \%$. The only significant differences were found for the $1000 \mathrm{~m}$ pixel size; they decreased with the increase in study area (V̌̌emina catchment 32.28\%, Dřevnice catchment 9.64\%). For the whole Czech Republic, the difference was again negligible $(0.52 \%)$ compared to the $1 \mathrm{~m}$ pixel size.

\subsection{Effect of Data with Different Pixel Sizes on the Carbon Estimation at the Regional Scale}

When comparing the carbon-stock estimations at the regional level, differences no larger than $4 \%$ were found in the monitored areas. Interestingly, the largest carbon stock was estimated based on the data set with a $100 \mathrm{~m}$ (Všemina catchment and the Czech Republic) or 1000 m (Dřevnice catchment) pixel size.

\section{Discussion}

The comparison of carbon-stock estimation based on local-scale data $(1: 10,000)$ and regional-scale data $(1: 100,000)$ in vector form showed lower carbon stock in all three study areas calculated using regional CLC data than carbon stock based on local data from the detailed combined layer. This can be explained by the more precise delineation of segments and a more accurate area determination of individual rarer, natural, or seminatural habitats that are less widely represented in the study area and therefore not present in regional maps [90,93]. However, these habitats can have a larger carbon stock compared to the most widespread habitats; the variability in carbon stock in different forest species and forest habitats was reported, for example [99-101,104].

The differences between the vector and raster form of the same input layer can be explained by the vector layer rasterization algorithm, which manifests in the smoothing of perimeter lines; as a result, the areas of some habitats decrease, thereby also decreasing the carbon stock. After rasterization of the vector layer with a clearly defined boundary, the produced pixels fill only the inner space of the polygon [4]. If a created pixel crosses the polygon boundary and most of its area is in the polygon surroundings, it would not be created. As a result, the number of valid polygons and their areas that are included in the total area decrease $[47,90]$. The rasterization process creates homogenized square cells (pixels); as the pixel edge size increases, the area it covers also increases, with a resulting decrease in the number of pixels needed to cover the entire area [103]. In this case, the probability of the carbon-stock values not being reflected in the resulting pixel value, given by the value of the pixel with the predominant area, increases. If these small habitats contain shrubs or trees, which usually have a higher carbon-stock value, the total calculated stock decreases with increasing raster size. When applied to a larger area with a higher number of segments, this inaccuracy probably decreases due to error compensation while assigning carbon-stock values to individual pixels [32,35]. Based on a comparison of carbon-stock estimates at the local level using rasterized data with different pixel sizes, we found that increasing the pixel size can remarkably decrease the calculated carbon-stock estimates depending on the size and shape of the study area.

When using the LUT method, the smaller area is multiplied by expert values. The more the shape of the rasterized polygon differs from a square, the more the number of valid pixels (which form the rasterized image of the area) decreases [105]. The smaller the area and, concurrently, the larger the pixel requirement in the rasterization process, the more pronounced is the deviation from the reference value computed from the studied area in vector format [64].

The results of comparing carbon stocks from rasterized data with different pixel sizes at the local level further showed that increasing pixel size can significantly reduce the calculated carbon stocks depending on the size and shape of the area of interest. Only the largest pixel size from the tested raster $(1000 \mathrm{~m})$ had a stronger effect on the carbon-stock results in both Dřevnice catchment-the difference from results computed from vector data 
was $10 \%$ - and, particularly, in Všemina catchment, the smallest catchment area, where the difference was $32 \%$ (Table 3). The carbon stock calculated using raster format with a $100 \mathrm{~m}$ pixel size decreased in both catchments by only $2 \%$. At the scale of the whole Czech Republic, practically no difference was found, even when the raster with a $1000 \mathrm{~m}$ pixel size was applied. Unfortunately, the analysis was limited to three study areas with sizes of $21.5,435$, and $78,866 \mathrm{~km}^{2}$; therefore, it was not possible to determine the size of the area where this phenomenon no longer manifests. Zhao et al. [81] monitored the effect of spatial resolution on the carbon sequestration at the regional level $\left(3852 \mathrm{~km}^{2}\right)$. The carbon sequestration rate remained relatively stable (changes within $10 \%$ ) when the resolution changed from 250 to $10,000 \mathrm{~m}$. We detected a considerable decrease of 33\% when the resolution was further degraded to $2000 \mathrm{~m}$. The suitability of the spatial grain of $1 \mathrm{~km}^{2}$ is also recommended by the work of Hoskins et al. [84], in which it is more relevant to ecological processes at the local and regional scale.

The carbon stock estimated on the basis of rasterized data at the regional level from CLC data with various pixel sizes had similar trends in both the Všemina catchment and the Czech Republic. In both cases, the calculated carbon stock was highest in the raster with 100 m pixels and lowest in the raster with 1000 m pixels; in the Dřevnice catchment, the highest carbon-stock value was in the raster with $1000 \mathrm{~m}$ pixels and lowest in the raster with $100 \mathrm{~m}$ pixels. However, the differences were slight between the carbon-stock values estimated on the basis of various rasters, with the largest reaching only 3.75\%. The accuracy and reliability of vegetation carbon-stock estimates relies also on the quality of the land-cover mapping process. Muñoz-Rojas et al. [87] studied approximately the same size territory at the regional scale, used CLC mapping, and noted that phenomenon too. In our study, we solved the problem of broadly defined CLC categories by a detailed analysis of habitat content in all CLC categories [94,95].

Considering the differences in the number of segments of the individual tested layers (Table 5), which could theoretically lead to large divergence in accuracy, the relatively low differentiation (up to $10 \%$ ) of carbon-stock values, calculated on the basis of various landscape matrices, was rather surprising. The only exception was the smallest area, the Všemina catchment, using the largest raster with a $1000 \mathrm{~m}$ pixel size, as mentioned above. This contradicted the general assumption that such differences in the number of segments, and therefore in their average size, affect landscape structures and thus the associated ecosystem functions of the landscape [106]. Comparing the number of segments composing a landscape matrix revealed that the number of landscape matrix segments in vector form at the regional level (38 in Všemina catchment, 391 in Dřevnice catchment, and 45,982 in the Czech Republic) was closest to the number of segments in raster form with the $1000 \mathrm{~m}$ pixel size (21 in Všemina catchment, 429 in Dřevnice catchment, and 78,637 in the Czech Republic). Perhaps this was related to the approximation of the values of carbon stocks from the raster form at the regional level to the results obtained on the basis of the landscape matrix in vector form at the regional level.

Expert estimations of carbon values in habitats have been conducted since 2010, which were determined as the average maximum biomass value. For the forest carbon stock estimation in this study, we used data from the CzechTerra landscape inventory system [69]. This system is based on data collected from a systematic grid with $7 \times 7 \mathrm{~km}$ cells, providing 1599 randomly distributed plot locations (within each cell) across the entire Czech Republic, which was carried out in two cycles, 2008-2009 and 2014-2015. Data from this system enabled the determination of changes in forest carbon stock in this 6-year period and showed an increase in aboveground tree biomass from 102 to $111 \mathrm{tC} \times \mathrm{ha}^{-1}$, amongst other things [101]. From the annual increase in tree biomass based on these data, together with the annual timber harvesting data, we arrived at an estimate of $\mathrm{C}$ stocks in forests for 2020: $112.4 \mathrm{tC} \times \mathrm{ha}^{-1}$, mainly due to bark beetle calamity, leading to higher logging in past years. For example, in 2019, twice as much wood was felled as the average for 2009-2015 [102]. However, this estimate can be affected by uncertainties resulting from the input data, mainly by estimated biomass growth derived from a previous survey of the 
CzechTerra landscape inventory system, which was performed in the period prior to the bark-beetle infestation and applied to 2016-2020, which was influenced by the bark-beetle disaster [75].

Another source of uncertainty may be data on logging, reported in official sources [102], which could be underestimated as reported, for example, by Černý et al. [101]. In addition, data on logging from 2020 are not yet available, so we used data from 2019 in our estimates. Lastly, carbon stock estimates in forests are influenced by mathematical models for calculating the tree volume used in the CzechTerra landscape inventory system [107]. As noted by Černý et al. [101], if, for example, older tree volume tables are used for the forest carbon stock estimate, the estimate would be approximately $6.7 \%$ higher compared to results using the Czech Terra landscape inventory. According to our estimate of forest carbon-stock development, the trend in increasing carbon stock in forests began to reverse in 2019, and carbon stock began to decline mainly due to record high harvests caused by the bark-beetle infestation. However, the Ministry of Agriculture reported an increase in wood stocks in forests in 2019 [102]. If the trend in forest carbon-stock increase continues despite ongoing bark-beetle infestation and the rapidly increasing logging in past three years, the carbon stock could be approximately $4 \%$ higher compared to our estimate.

Future studies must focus on using at least one method of aboveground biomass assessment that is independent of the remote-sensing approach [26]; an average estimate and its deviation should be reported. However, the coupling of three current methodologies, e.g., field techniques, using forest inventory data, and satellite data in several areas and gradients within areas, would be desirable $[7,14,62]$. Although the combination of these techniques requires costly resources, a wide range of professional skills, and improved technologies, more precise approximations of the aboveground biomass could reduce the costs of regional biomass assessments [10].

\section{Conclusions}

This choice of the form of expression and scale of input data plays a key role in the assessment of carbon stocks, as it defines the basic matrix for expressing the heterogeneity of the environment, the quality (naturalness) of habitats, and the expression of detail (in the geometric and descriptive parts). The uncertainty of this determination is influenced by many factors, especially by the quality of the input data and the method of determining the captured carbon. The comparison of carbon stocks using different input matrices at various scales did not produce differences greater than $6 \%$. The subsequent rasterization of the vector landscape matrix changed the results only with the largest raster size of $1000 \mathrm{~m}$ applied at the local scale, especially for the smallest studied area-Všemina catchment, with an area of $22 \mathrm{~km}^{2}$. The results confirmed the need to use similar sources of input data and the same input matrix for their implementation at the landscape level when calculating carbon stocks for national inventories.

Author Contributions: Conceptualization, V.P. and P.C.; methodology, V.P., E.C., L.Š. and P.C.; software V.P. and P.V.; validation, J.P., L.Š. and O.C.; formal analysis, P.V., R.V. and L.Š.; resources, V.P., J.P., R.V. and M.P.; data acquisition, V.P., E.C., L.S., R.V. and P.C.; writing-original draft preparation, V.P., J.P., O.C., L.Š. and P.C.; writing—-review and editing, V.P., O.C. and P.C.; supervision, P.C.; project administration, P.C.; funding acquisition, P.C. All authors have read and agreed to the published version of the manuscript.

Funding: This work was supported by the Ministry of Education, Youth and Sports of CR within the CzeCOS program (grant number LM2018123), SustES, Adaptation strategies for sustainable ecosystem services and food security under adverse environmental conditions (CZ.02.1.01/0.0/0.0/16_019/0000797), and the project "Small watercourses and riparian ecosystem management to mitigate the impacts of environmental change (SMART2Envi)", Reg. No. LTC18069.

Institutional Review Board Statement: Not applicable.

Informed Consent Statement: Not applicable. 
Data Availability Statement: The data used to support the findings of this study are available from the corresponding author upon request.

Conflicts of Interest: The authors declare that they have no known competing financial interests or personal relationships that could have appeared to influence the work reported in this paper.

\section{References}

1. Robinson, D. Implications of a large global root biomass for carbon sink estimates and for soil carbon dynamics. Proc. R. Soc. B Biol. Sci. 2007, 274, 2753-2759. [CrossRef]

2. Raupach, M.R. Pinning down the land carbon sink. Nat. Clim. Chang. 2011, 1, 148-149. [CrossRef]

3. Schindler, D.E.; Hilborn, R.; Chasco, B.; Boatright, C.P.; Quinn, T.P.; Rogers, L.A.; Webster, M.S. Population diversity and the portfolio effect in an exploited species. Nature 2010, 465, 609-612. [CrossRef] [PubMed]

4. Tallis, H.; Ricketts, T.; Guerry, A.; Nelson, E.; Ennaanay, D.; Wolny, S.; Olwero, N.; Vigerstol, K.; Pennington, D.; Mendoza, G.; et al. InVEST 2.1 Beta User Guide; Stanford University: Stanford, CA, USA, 2011.

5. Powlson, D.S.; Whitmore, A.P.; Goulding, K.W.T. Soil carbon sequestration to mitigate climate change: A critical re-examination to identify the true and the false. Eur. J. Soil Sci. 2011, 62, 42-55. [CrossRef]

6. Cienciala, E.; Henžlík, V.; Zatloukal, V. Assessment of Carbon Stock Change in Forests-Adopting IPCC LULUCF Good Practice Guidance in the Czech Republic. Forestry J. 2006, 52, 17-28.

7. Ravindranath, N.H.; Ostwald, M. Methods for estimating above-ground biomass. In Advances in Global Change Research; Springer International Publishing: Berlin/Heidelberg, Germany, 2008; pp. 113-147. [CrossRef]

8. Smith, P.; Soussana, J.F.; Angers, D.; Schipper, L.; Chenu, C.; Rasse, D.P.; Batjes, N.H.; van Egmond, F.; McNeill, S.; Kuhnert, M.; et al. How to measure, report and verify soil carbon change to realize the potential of soil carbon sequestration for atmospheric greenhouse gas removal. Glob. Chang. Biol. 2020, 26, 219-241. [CrossRef]

9. Vashum, K.T.; Jayakumar, S. Methods to Estimate Above-Ground Biomass and Carbon Stock in Natural Forests-A Review. J. Ecosyst. Ecography 2012, 2, 1-7. [CrossRef]

10. Main-Knorn, M.; Moisen, G.G.; Healey, S.P.; Keeton, W.S.; Freeman, E.A.; Hostert, P. Evaluating the Remote Sensing and Inventory-Based Estimation of Biomass in the Western Carpathians. Remote Sens. 2011, 3, 1427-1446. [CrossRef]

11. Bi, H.; Turner, J.; Lambert, M.J. Additive biomass equations for native eucalypt forest tress of temperate Australia. Trees 2004, 18, 467-479. [CrossRef]

12. Kimball, J.S.; Keyser, A.R.; Running, S.W.; Saatchi, S.S. Regional assessment of boreal forest productivity using an ecological process model and remote sensing parameter maps. Tree Physiol. 2000, 20, 761-775. [CrossRef]

13. Schröder, B. Challenges of species distribution modeling belowground. J. Plant Nutr. Soil Sci. 2008, 171, 325-337. [CrossRef]

14. Powell, S.L.; Cohen, W.B.; Healey, S.P.; Kennedy, R.E.; Moisen, G.G.; Pierce, K.B.; Ohmann, J.L. Quantification of live aboveground forest biomass dynamics with Landsat time-series and field inventory data: A comparison of empirical modeling approaches. Remote Sens. Environ. 2010, 114, 1053-1068. [CrossRef]

15. Main-Knorn, M.; Cohen, W.B.; Kennedy, R.E.; Grodzki, W.; Pflugmacher, D.; Griffiths, P.; Hostert, P. Monitoring coniferous forest biomass change using a Landsat trajectory-based approach. Remote Sens. Environ. 2013, 139, 277-290. [CrossRef]

16. Kareiva, P.; Polasky, S.; Tallis, H.; Ricketts, T.H.; Daily, G.C. Natural Capital: Theory and Practice of Mapping Ecosystem Services; Oxford University Press: Oxford, UK, 2011.

17. Bottalico, F.; Pesola, L.; Vizzarri, M.; Antonello, L.; Barbati, A.; Chirici, G.; Corona, P.; Cullotta, S.; Garfi, V.; Giannico, V.; et al Modeling the influence of alternative forest management scenarios on wood production and carbon storage: A case study in the Mediterranean region. Environ. Res. 2016, 144, 72-87. [CrossRef] [PubMed]

18. Pechanec, V.; Purkyt, J.; Benc, A.; Nwaogu, C.; Štěrbová, L.; Cudlín, P. Modelling of the carbon sequestration and its prediction under climate change. Ecol. Inform. 2018, 47, 50-54. [CrossRef]

19. Asner, G.P.; Sousan, S.; Knapp, D.E.; Selmants, P.C.; Martin, R.E.; Hughes, R.F.; Giardina, C.P. Rapid forest carbon assessments of oceanic islands: A case study of the Hawaiian archipelago. Carbon Balance Manag. 2016, 11, 1-13. [CrossRef]

20. Powlson, D.S.; Bhogal, A.; Chambers, B.J.; Coleman, K.; Macdonald, A.J.; Goulding, K.W.T.; Whitmore, A.P. The potential to increase soil carbon stocks through reduced tillage or organic material additions in England and Wales: A case study. Agric. Ecosyst. Environ. 2012, 146, 23-33. [CrossRef]

21. TEEB. Mainstreaming the Economics of Nature: A synthesis of the Approach, Conclusions and Recommendations of TEEB; TEEB-The Economics of Ecosystems and Biodiversity: Geneva, Switzerland, 2010.

22. Eggleston, H.S.; Miwa, K.; Srivastava, N.; Tanabe, K. (Eds.) IPCC Guidelines for National Greenhouse Inventories-A Primer, Prepared by the National Greenhouse Gas Inventories Programme; Iges: Hayama, Japan, 2006.

23. Canadell, J.G.; Raupach, M.R. Managing forests for climate change mitigation. Science 2008, 320, 1456-1457. [CrossRef] [PubMed]

24. Pagiola, S. Payments for environmental services in Costa Rica. Ecol. Econ. 2008, 65, 712-724. [CrossRef]

25. Carpenter, S.R.; Mooney, H.A.; Agard, J.; Capistrano, D.; Defries, R.S.; Diaz, S.; Dietz, T.; Duraiappah, A.K.; Oteng-Yeboah, A.; Pereira, H.M.; et al. Science for managing ecosystem services: Beyond the Millennium Ecosystem Assessment. Proc. Natl. Acad. Sci. USA 2009, 106, 1305-1312. [CrossRef] [PubMed]

26. Norgaard, R.B. Ecosystem services: From eye-opening metaphor to complexity blinder. Ecol. Econ. 2010, 69, 1219-1227. [CrossRef] 
27. Daily, G.C.; Polasky, S.; Goldstein, J.; Kareiva, P.M.; Mooney, H.A.; Pejchar, L.; Ricketts, T.H.; Salzman, J.; Shallenberger, R. Ecosystem services in decision making: Time to deliver. Front. Ecol. Environ. 2009, 7, 21-28. [CrossRef]

28. Potschin, M.B.; Haines-Young, R.H. Ecosystem services. Prog. Phys. Geogr. Earth Environ. 2011, 35, 575-594. [CrossRef]

29. De Groot, R.S.; Wilson, M.A.; Boumans, R.M.J. A typology for the classification, description and valuation of ecosystem functions, goods and services. Ecol. Econ. 2002, 41, 393-408. [CrossRef]

30. Lyons, K.G.; Brigham, C.A.; Traut, B.H.; Schwartz, M.W. Rare species and ecosystem functioning. Conserv. Biol. 2005, 19, 1019-1024. [CrossRef]

31. Bellwood, D.R.; Streit, R.P.; Brandl, S.J.; Tebbett, S.B. The meaning of the term 'function' in ecology: A coral reef perspective Funct. Ecol. 2019, 33, 948-961. [CrossRef]

32. Pettorelli, N.; Schulte to Bühne, H.; Tulloch, A.; Dubois, G.; Macinnis-Ng, C.; Queirós, A.M.; Keith, D.A.; Wegmann, M.; Schrodt, F.; Stellmes, M.; et al. Satellite remote sensing of ecosystem functions: Opportunities, challenges and way forward. Remote Sens. Ecol. Conserv. 2018, 4, 71-93. [CrossRef]

33. Costanza, R.; Folke, C. Valuing ecosystem services with efficiency, fairness, and sustainability as goals. In Nature's Services: Societal Dependence on Natural Ecosystems; Daily, G., Ed.; Island Press: Washington, DC, USA, 1997; pp. 49-68.

34. Daily, G.C.; Söderqvist, T.; Aniyar, S.; Arrow, K.; Dasgupta, P.; Ehrlich, P.R.; Folke, C.; Jansson, A.M.; Jansson, B.O.; Kautsky, N.; et al. Value of nature and the nature of value. Science 2000, 289, 395-396. [CrossRef]

35. Nedkov, S.; Burkhard, B. Flood regulating ecosystem services-Mapping supply and demand, in the Etropole municipality, Bulgaria. Ecol. Indic. 2012, 21, 67-79. [CrossRef]

36. Jax, K. Function and "functioning" in ecology: What does it mean? Oikos 2005, 111, 641-648. [CrossRef]

37. Petter, M.; Mooney, S.; Maynard, S.M.; Davidson, A.; Cox, M.; Horosak, I. A methodology to map ecosystem functions to support ecosystem services assessments. Ecol. Soc. 2013, 18, 31. [CrossRef]

38. Meyer, S.T.; Koch, C.; Weisser, W.W. Towards a standardized Rapid Ecosystem Function Assessment (REFA). Trends Ecol. Evol. 2015, 30, 390-397. [CrossRef] [PubMed]

39. Kandziora, M.; Burkhard, B.; Müller, F. Interactions of ecosystem properties, ecosystem integrity and ecosystem service indicators: A theoretical matrix exercise. Ecol. Indic. 2013, 28, 54-78. [CrossRef]

40. Burkhard, B.; Kandziora, M.; Hou, Y.; Müller, F. Ecosystem service potentials, flows and demands-concepts for spatial localization, indication and quantification. Landsc. Online 2014, 34, 1-32. [CrossRef]

41. Potschin, M.; Haines-Young, R. Defining and measuring ecosystem services. In Routledge Handbook of Ecosystem Services; Routledge: London, UK, 2016; pp. 25-44. [CrossRef]

42. De Groot, R.S.; Alkemade, R.; Braat, L.; Hein, L.; Willemen, L. Challenges in integrating the concept of ecosystem services and values in landscape planning, management and decision making. Ecol. Complex. 2010, 7, 260-272. [CrossRef]

43. Maes, J.; Liquete, C.; Teller, A.; Erhard, M.; Paracchini, M.L.; Barredo, J.I.; Grizzetti, B.; Cardoso, A.; Somma, F.; Petersen, J.E.; et al An indicator framework for assessing ecosystem services in support of the EU Biodiversity Strategy to 2020. Ecosyst. Serv. 2016, 17, 14-23. [CrossRef]

44. Nelson, E.; Mendoza, G.; Regetz, J.; Polasky, S.; Tallis, H.; Cameron, D.R.; Chan, K.M.A.; Daily, G.C.; Goldstein, J.; Kareiva, P.M.; et al. Modeling multiple ecosystem services, biodiversity conservation, commodity production, and tradeoffs at landscape scales. Front. Ecol. Environ. 2009, 7, 4-11. [CrossRef]

45. Tallis, H.; Polasky, S. Mapping and Valuing Ecosystem Services as an Approach for Conservation and Natural-Resource Management. Year Ecol. Conserv. Biol. 2009, 1162, 265-283. [CrossRef]

46. Bagstad, K.J.; Semmens, D.J.; Waage, S.; Winthrop, R. A comparative assessment of decision-support tools for ecosystem services quantification and valuation. Ecosyst. Serv. 2013, 5, 27-39. [CrossRef]

47. Leh, M.D.K.; Matlock, M.D.; Cummings, E.C.; Nalley, L.L. Quantifying and mapping multiple ecosystem services change in West Africa. Agric. Ecosyst. Environ. 2013, 165, 6-18. [CrossRef]

48. Lal, R. Soil carbon dynamics in cropland and rangeland. In Environmental Pollution; Elsevier: Amsterdam, The Netherlands, 2002. [CrossRef]

49. Madeira, E.C.M. Policies to Reduce Emissions from Deforestation and Degradation (REDD) in Tropical Forests Policies to Reduce Emissions from Deforestation and Degradation (REDD) in Tropical Forests: An Examination of the Issues Facing the Incorporation of REDD into Market; Meadows Design Office Inc.: Washington, DC, USA, 2008.

50. Nabuurs, G.J.; Thürig, E.; Heidema, N.; Armolaitis, K.; Biber, P.; Cienciala, E.; Kaufmann, E.; Mäkipää, R.; Nilsen, P.; Petritsch, R.; et al. Hotspots of the European forests carbon cycle. For. Ecol. Manag. 2008, 256, 194-200. [CrossRef]

51. Smith, J.; Smith, P.; Wattenbach, M.; Zaehle, S.; Hiederer, R.; Jones, R.J.A.; Montanarella, L.; Rounsevell, M.D.A.; Reginster, I.; Ewert, F. Projected changes in mineral soil carbon of European croplands and grasslands, 1990-2080. Glob. Chang. Biol. 2005, 11, 2141-2152. [CrossRef]

52. Uchida, K.; Ushimaru, A. Biodiversity declines due to abandonment and intensification of agricultural lands: Patterns and mechanisms. Ecol. Monogr. 2014, 84, 637-658. [CrossRef]

53. Ward, S.E.; Smart, S.M.; Quirk, H.; Tallowin, J.R.B.; Mortimer, S.R.; Shiel, R.S.; Wilby, A.; Bardgett, R.D. Legacy effects of grassland management on soil carbon to depth. Glob. Chang. Biol. 2016, 22, 2929-2938. [CrossRef] [PubMed]

54. Lugato, E.; Bampa, F.; Panagos, P.; Montanarella, L.; Jones, A. Potential carbon sequestration of European arable soils estimated by modelling a comprehensive set of management practices. Glob. Chang. Biol. 2014, 20, 3557-3567. [CrossRef] 
55. Brown, S. Measuring carbon in forests: Current status and future challenges. Environ. Pollut. 2002, 116, 363-372. [CrossRef]

56. Coomes, D.A.; Allen, R.B.; Scott, N.A.; Goulding, C.; Beets, P. Designing systems to monitor carbon stocks in forests and shrublands. For. Ecol. Manag. 2002, 164, 89-108. [CrossRef]

57. Machar, I.; Simon, J.; Rejsek, K.; Pechanec, V.; Brus, J.; Kilianova, H. Assessment of Forest Management in Protected Areas Based on Multidisciplinary Research. Forests 2016, 7, 285. [CrossRef]

58. Goodenough, D.G.; Chen, H.; Dyk, A.; Han, T.; Li, J. Multisensor data fusion for above-ground carbon estimation. In Proceedings of the 28th General Assembly of the International Union of Radio Science (URSI), New Delhi, India, 23 October 2005; Volume 400, pp. 1-4.

59. Mandal, R.A.; van Laake, P. Carbon sequestration in community forests: An eligible issue for CDM (A case study of Nainital, India). Banko Janakari 2005, 15, 53-61. [CrossRef]

60. Vicharnakorn, P.; Shrestha, R.; Nagai, M.; Salam, A.; Kiratiprayoon, S. Carbon Stock Assessment Using Remote Sensing and Forest Inventory Data in Savannakhet, Lao PDR. Remote Sens. 2014, 6, 5452-5479. [CrossRef]

61. Jenkins, J.C.; Chojnacky, D.C.; Heath, L.S.; Birdsey, R.A. Comprehensive Database of Diameter-Based Biomass Regressions for North American Tree Species; Gen. Tech. Rep. NE-319; U.S. Department of Agriculture, Forest Service, Northeastern Research Station: Newtown Square, PA, USA, 2004; p. 45. [CrossRef]

62. Somogyi, Z.; Cienciala, E.; Mäkipää, R.; Muukkonen, P.; Lehtonen, A.; Weiss, P. Indirect methods of large-scale forest biomass estimation. Eur. J. For. Res. 2007, 126, 197-207. [CrossRef]

63. Zhang, X.; Zhao, Y.; Ashton, M.S.; Lee, X. Measuring carbon in forests. In Managing Forest Carbon in a Changing Climate; Springer: Berlin/Heidelberg, Germany, 2012; pp. 139-164. [CrossRef]

64. Ponce-Hernandez, R. Assessing Carbon Stocks and Modelling Win-Win Scenarios of Carbon Sequestration through Land-USE Changes; Food and Agriculture Organization of the United Nations: Rome, Italy, 2004.

65. Lehtonen, A.; Cienciala, E.; Tatarinov, F.; Mäkipää, R. Uncertainty estimation of biomass expansion factors for Norway spruce in the Czech Republic. Ann. For. Sci. 2007, 64, 133-140. [CrossRef]

66. Cienciala, E.; Altman, J.; Doležal, J.; Kopáček, J.; Štěpánek, P.; Ståhl, G.; Tumajer, J. Increased spruce tree growth in Central Europe since 1960s. Sci. Total Environ. 2018, 619-620, 1637-1647. [CrossRef] [PubMed]

67. Cruickshank, M.M.; Tomlinson, R.W.; Trew, S. Application of CORINE land-cover mapping to estimate carbon stored in the vegetation of Ireland. J. Environ. Manag. 2000, 58, 269-287. [CrossRef]

68. Sanga-Ngoie, K.; Iizuka, K.; Kobayashi, S. Estimating CO2 Sequestration by Forests in Oita Prefecture, Japan, by Combining LANDSAT ETM+ and ALOS Satellite Remote Sensing Data. Remote Sens. 2012, 4, 3544-3570. [CrossRef]

69. Hunt, E.R.; Fahnestock, J.T.; Kelly, R.D.; Welker, J.M.; Reiners, W.A.; Smith, W.K. Carbon sequestration from remotely-sensed NDVI and net ecosystem exchange. In From Laboratory Spectroscopy to Remotely Sensed Spectra of Terrestrial Ecosystems; Muttiah, R.S., Ed.; Kluwer Academi Publiser: Dordecht, The Netherlands, 2002; pp. 161-174. [CrossRef]

70. Marziliano, P.A.; Menguzzato, G.; Coletta, V. Evaluating Carbon Stock Changes in Forest and Related Uncertainty. Sustainability 2017, 9, 1702. [CrossRef]

71. Avitabile, V.; Baccini, A.; Friedl, M.A.; Schmullius, C. Capabilities and limitations of Landsat and land cover data for aboveground woody biomass estimation of Uganda. Remote Sens. Environ. 2012, 117, 366-380. [CrossRef]

72. Mund, M.; Kummetz, E.; Hein, M.; Bauer, G.A.; Schulze, E.D. Growth and carbon stocks of a spruce forest chronosequence in central Europe. For. Ecol. Manag. 2002, 171, 275-296. [CrossRef]

73. Fehrmann, L.; Kleinn, C. General considerations about the use of allometric equations for biomass estimation on the example of Norway spruce in central Europe. For. Ecol. Manag. 2006, 236, 412-421. [CrossRef]

74. Niklas, K.J. Plant allometry: Is there a grand unifying theory? Biol. Rev. Camb. Philos. Soc. 2004, 79, 871-889. [CrossRef]

75. Stephenson, N.L.; Das, A.J.; Condit, R.; Russo, S.E.; Baker, P.J.; Beckman, N.G.; Coomes, D.A.; Lines, E.R.; Morris, W.K.; Rüger, N.; et al. Rate of tree carbon accumulation increases continuously with tree size. Nature 2014, 507, 90-93. [CrossRef]

76. Schöne, D.; Schulte, A. Forestry after Kyoto: Quantifying and utilizing carbon sinks in practice. Forstarchiv 1999, 70, 167-176.

77. Pechanec, V.; Stržínek, F.; Purkyt, J.; Šterbová, L.; Cudlín, P. Carbon stock in forest above-ground biomass-Comparison based on Landsat data. Cent. Eur. For. J. 2017, 63, 126-132. [CrossRef]

78. Liebens, J.; van Molle, M. Influence of estimation procedure on soil organic carbon stock assessment in Flanders, Belgium. Soil Use Manag. 2003, 19, 364-371. [CrossRef]

79. Lu, D.; Chen, Q.; Wang, G.; Moran, E.; Batistella, M.; Zhang, M.; Vaglio Laurin, G.; Saah, D. Aboveground Forest Biomass Estimation with Landsat and LiDAR Data and Uncertainty Analysis of the Estimates. Int. J. For. Res. 2012, 2012, 1-16. [CrossRef]

80. Asner, G.P.; Mascaro, J.; Anderson, C.; Knapp, D.E.; Martin, R.E.; Kennedy-Bowdoin, T.; van Breugel, M.; Davies, S.; Hall, J.S.; Muller-Landau, H.C.; et al. High-fidelity national carbon mapping for resource management and REDD+. Carbon Balance Manag. 2013, 8, 7. [CrossRef]

81. Zhao, S.Q.; Liu, S.; Li, Z.; Sohl, T.L. A spatial resolution threshold of land cover in estimating terrestrial carbon sequestration in four counties in Georgia and Alabama, USA. Biogeosciences 2010, 7, 71-80. [CrossRef]

82. Féret, J.; Boissieu, F. biodivMapR: An r package for $\alpha$ - and $\beta$-diversity mapping using re-motely sensed images. Methods Ecol. Evol. 2020, 11, 64-70. [CrossRef]

83. Stellmes, M.; Udelhoven, T.; Röder, A.; Sonnenschein, R.; Hill, J. Dryland observation at local and regional scale—Comparison of Landsat TM/ETM+ and NOAA AVHRR time series. Remote Sens. Environ. 2010, 114, 2111-2125. [CrossRef] 
84. Hoskins, A.J.; Bush, A.; Gilmore, J.; Harwood, T.; Hudson, L.N.; Ware, C.; Williams, K.J.; Ferrier, S. Downscaling land-use data to provide global 30" estimates of five land-use classes. Ecol. Evol. 2016, 6, 3040-3055. [CrossRef]

85. Leitão, P.J.; Schwieder, M.; Pötzschner, F.; Pinto, J.R.R.; Teixeira, A.M.C.; Pedroni, F.; Sanchez, M.; Rogass, C.; van der Linden, S.; Bustamante, M.M.C.; et al. From sample to pixel: Multi-scale remote sensing data for upscaling aboveground carbon data in heterogeneous landscapes. Ecosphere 2018, 9, e02298. [CrossRef]

86. Gustafson, E.J. Quantifying landscape spatial pattern: What is the state of the art? Ecosystems 1998, 1, 143-156. [CrossRef]

87. Muñoz-Rojas, M.; de la Rosa, D.; Zavala, L.M.; Jordán, A.; Anaya-Romero, M. Changes in land cover and vegetation carbon stocks in Andalusia, Southern Spain (1956-2007). Sci. Total Environ. 2011, 409, 2796-2806. [CrossRef]

88. Sahle, M.; Saito, O.; Fürst, C.; Yeshitela, K. Quantification and mapping of the supply of and demand for carbon storage and sequestration service in woody biomass and soil to mitigate climate change in the socio-ecological environment. Sci. Total Environ. 2018, 624, 342-354. [CrossRef] [PubMed]

89. Kucuker, D.M. Spatiotemporal changes of carbon storage in forest carbon pools of Western Turkey: 1972-2016. Environ. Monit. Assess. 2020, 192, 1-18. [CrossRef]

90. Longley, P.A.; Goodchild, M.; Maguire, D.J.; Rhind, D.W. Geographic Information Systems and Science, 3rd.; Wiley: Hoboken, NJ, USA, 2010

91. Pechanec, V.; Kilianová, H.; Tangwa, E.; Vondráková, A.; Machar, I. What is the Development Capacity for Provision of Ecosystem Services in the Czech Republic? Sustainability 2019, 11, 4273. [CrossRef]

92. Pechanec, V.; Cudlín, P.; Machar, I.; Brus, J.; Kilianová, H. Modelling of the Water Retention Capacity of the Landscape; Springer: Berlin/Heidelberg, Germany, 2020; pp. 225-248. [CrossRef]

93. Bossard, M.; Feranec, J.; Otahel, J.; Steenmans, C. CORINE Land Cover Technical Guide-Addendum 2000; European Environmental Agency: København, Denmark, 2000.

94. Šímová, P.; Černý, M.; Cienciala, E.; Apltauer, J.; Kučerová, J.; Beranová, J.; Drahoňovská, E. A methodology for classifying aerial photographs within the CzechTerra landscape inventory system: A new approach to generating data for landscape analyses. J. Landsc. Stud. 2009, 2, 43-55.

95. Chytrý, M.; Kučera, T.; Kočí, M.; Grulich, V.; Lustyk, P. Catalog of Habitats of the Czech Republic, 2nd ed.; Nature Conservation Agency of the Czech Republic: Prague, Czech Republic, 2010; p. 447. (In Czech)

96. Seják, J.; Dejmal, I. (Eds.) Assessment and Valuation of Habitats of the Czech Republic; Czech Ecological Institute: Prague, Czech Republic, 2003. (In Czech)

97. Frélichová, J.; Vačkář, D.; Pártl, A.; Loučková, B.; Harmáčková, Z.V.; Lorencová, E. Integrated assessment of ecosystem services in the Czech Republic. Ecosyst. Serv. 2014, 8, 110-117. [CrossRef]

98. Seják, J.; Cudlín, P.; Petříček, V.; Prokopová, M.; Cudlín, O.; Holcová, D.; Melichar, J.; Škarková, P. Habitat Assessment Methodology of NCA CR 2017; Nature Conservation Agency of the Czech Republic: Prague, Czech Republic, 2017. (In Czech)

99. Stará, L.; Matějka, K.; Cudlín, P.; Bodlák, L.; Pokorný, J.; Středa, T.; Čížková, H.; Pechar, L.; Burešová, R.; Zemek, F.; et al. Carbon supply in the vegetation of the Czech Republic and model carbon balance of the landscape. In Carbon in the Ecosystems of the Czech Republic under Changing Climate; Academia: Prague, Czech Republic, 2011. (In Czech)

100. Cienciala, E.; Černý, M.; Russ, R.; Zatloukal, V.; Holá, Š.; Palán, Š. Landscape Inventory CzechTerra Selected Inventory Results 2008/2009 and 2014/2015; IFER Supplement in Lesnická Práce; IFER: Prague, Czech Republic, 2015.

101. Černý, M.; Cienciala, E.; Zatloukal, V. CzechTerra landscape inventory. What does the repeated survey from $2008 / 2009$ and 2014/2015 show? Lesnická Práce 2015, 10, 33-35. (In Czech)

102. Mze, C.R. Report on the State of Forests and Forest Management in the Czech Republic in 2019; Ministry of Agriculture: Prague, Czech Republic, 2000. (In Czech)

103. Shekhar, S.; Xiong, H.; Zhou, X. (Eds.) Encyclopedia of GIS, 2nd ed.; Springer International Publishing: Berlin/Heidelberg, Germany, 2017.

104. Latte, N.; Colinet, G.; Fayolle, A.; Lejeune, P.; Hébert, J.; Claessens, H.; Bauwens, S. Description of a new procedure to estimate the carbon stocks of all forest pools and impact assessment of methodological choices on the estimates. Eur. J. Forest Res. 2013, 132, 565-577. [CrossRef]

105. Wade, T.G.; Wickham, J.D.; Nash, M.S.; Neale, A.C.; Riitters, K.H.; Jones, K.B. A Comparison of Vector and Raster GIS Methods for Calculating Landscape Metrics Used in Environmental Assessments. Photogramm. Eng. Remote Sens. 2003, 69, $1399-1405$. [CrossRef]

106. Meneses, B.; Reis, E.; Reis, R.; Vale, M. The Effects of Land Use and Land Cover Geoinformation Raster Generalization in the Analysis of LUCC in Portugal. ISPRS Int. J. Geo-Inf. 2018, 7, 390. [CrossRef]

107. Černý, M.; Pařez, J. Determining the volume and assortment of standing trees using a trunk shape model. Lesnická Práce 2005, 84, 22-25. (In Czech) 